\title{
PENGUASAAN TANAH MASYARAKAT HUKUM ADAT (SUATU KAJ IAN TERHADAP MASYARAKAT HUKUM ADAT TERNATE)
}

\author{
Husen Alting \\ Fakultas Hukum Universitas Khairun \\ E-mail: husenalting@yahoo.com
}

\begin{abstract}
Land acquisation by the community of adat law tends to leave out. This condition caused by the government policy before which has no attention to the development of land acquisition of the adat community. According that policy, all land are owned by the State, especially when its issue is about the government and bussiness interest. Reformation has changed the State system related to land acquisition, where the position of adat law community is diclared explicitly in the State constitution. The position of adat law community is agreed as long as not contradicted wiht public interest. The tale of seeking the existency of adat law community and the right of adat land acquisition shows that acquisition, mechanism and the area of adat law community still exist and have different characteristic between one and another. So that, State and the government should give protection and agreement to the right of adat law community as well as local wisdom as stated in its constitution.
\end{abstract}

Key words: Land acquisation, right of adat community, adat law

\begin{abstract}
Abstrak
Pada saat ini, penguasaan tanah oleh masyarakat hukum adat cenderung untuk ditinggalkan. Kondisi ini disebabkan oleh kebijakan pemerintah yang tidak memperhatikan perkembangan penguasaan tanah oleh masyarakat hukum adat. Berdasarkan kebijakan tersebut, tanah dikuasai oleh Negara, khususnya ketika mucul isu yang berhubungan dengan kepentingan Negara dan bisnis. Dalam perkembangannya, reformasi telah mengubah sistem ketatanegaraan yang berkaitan dengan penguasaan tanah, dimana kedudukan masyarakat hukum adat dinyatakan secara eksplisit dalam konstitusi Negara. Kedudukan masyarakat hukum adat pada dasarnya diakui, selama tidak bertentangan dengan kepeentingan umum. Pencarian atas keberadaan masyarakat hukum adat dan hak penguasaan tanah menunjukan bahwa penguasaan, mekanisme, dan wilayah masyarakat hukum adat masih ada dan memiliki karakteristik yang berbeda antara yang satu dan yang lainya. Sehingga Negara dan pemerintah harus memberikan perlindungan terhadap hak masyarakat hukum adat sebagai kearifan lokal yang tercantum dalam konstitusi Negara dan.
\end{abstract}

Kata kunci: Penguasaan tanah, hak masyarakat adat, hukum Adat

\section{Pendahuluan}

Bangsa Indonesia sebagai negara kesatuan menempatkan tanah pada kedudukan yang penting, karena merupakan faktor yang tidak dapat dipisahkan dengan kondisi masyarakat Indonesia yang bercorak agraris. Selama pemerintahan Kolonial Belanda, tanah milik masyarakat Indonesia dirampas dan digunakan untuk kepentingan pemerintah kolonial. Kekuatan politik dan hukum pertahanan yang tidak berkeadilan, dimunculkan demi kemakmuran bangsa Belanda dan bahkan cenderung mengarah pada kapitalisme pertahanan.

Guna melakukan perubahan hukum agar memberikan penghidupan dan keadilan agraria bagi masyarakat, maka Majelis Permusyawaratan Rakyat mengeluarkan TAP MPR No.IX/MPR/ 2001 tentang Pembaharuan Agraria dan PengeIolaan Sumber Daya Alam, sebagai landasan kebijakan pertanahan nasional (national land policy), termasuk pengaturan hak masyarakat hukum adat dalam pemanfaatan tanah, walaupun sampai saat ini masih banyak kalangan 
yang meragukan eksistensinya terhadap perlindungan hak masyarakat adat. Achmad Sodiki menyebutkan sekalipun kekayaan alam telah dikuras habis tetapi masyarakat setempat kurang mendapatkan manfaatnya. ${ }^{1}$

Melalui prinsip dan arah pembaharuan agraria serta perubahan paradigma pengelolaan pemerintah desentralistik melalui pemberian otonomi yang bertanggung jawab kepada daerah, dikeluarkanlah Keppres Nomor 34 tahun 2003 dimana sebagian kewenangan pemerintah dibidang pertanahan dilaksanakan oleh pemerintah kabupaten/kota termasuk didalamnya penetapan dan penyelesaian masalah tanah ulayat. $^{2}$

Berdasarkan ketentuan tersebut, hak masyarakat hukum adat haruslah benar-benar masih ada dan tidak diberikan peluang untuk diadakan kembali. Keberadaan tersebut harus diikuti dengan hubungan pemanfaatan antara tanah dan masyarakat. Sedangkan masyarakat yang dimaksud adalah sekelompok orang yang terikat oleh tatanan hukum adatnya, sebagai warga bersama suatu persekutuan hukum, karena kesamaan tempat tinggal atau karena keturunan yang dikenal dengan berbagai nama yang berbeda tiap daerah.

Maluku Utara yang dikenal (Moloku Kie Raha) sebagai daerah kerajaan (Ternate, Tidore, Bacan, dan Jailolo), sejak lama telah mengenal adat-kebiasaan yang mengatur kehidupan masyarakat termasuk penguasaan dan pengelolaan sumberdaya alam tanah. Sistem penguasaan tanah dikenal dalam bentuk kepemilikan pribadi dan sistem kepemilikan komunal, seperti penguasaan tanah dalam bentuk hak sultan (aha kolano), hak soa (aha soa)

Achmad Sodiki, "Kebijakan Sumber Daya Alam dan Implikasi J uridisnya Pasca TAP MPR N IX/MPR/ 2001 dan Kepres No 34 tahun 2003", makalah disampaikan dalam Seminar Nasional "Eksistensi dan Kewenangan BPN Pasca Keppres No. 34 tahun 2003. Malang, hlm. 8; Lihat dan bandingkan dengan J ohn Haba, "Realitas Masyarakat Adat di Indonesia; Sebuah Realitas", J urnal Masyarakat dan Budaya LIPI J akarta, Vol. 12 No. 2, Tahun 2010, hlm. 255-285.

2 Sebelumnya telah ada Keputusan Menteri Negara Agraria/ Kepala Badan Pertanahan Nasional No 5 tahun 1999 sebagai pedoman penyelesaian masalah hak ulayat masyarakat hukum adat bagi daerah otonom. Lihat J uga PP 38 Tahun 2007 tentang Pembagian Urusan Pemerintah, Pemerintah Provinsi dan Pemerintah Kabupaten/Kota. dan hak cocatu (aha cocatu) yang mempunyai fungsi dan kedudukan yang berbeda-beda. Untuk aha kolano diperuntukan untuk sultan dan tidak dipungut pajak dari hasil tanah tersebut. Aha Soa (soa=kampung) adalah tanah pemberian sultan kepada marga dan tidak diperbolehkan dilakukan jual beli sedangkan tanah aha cocatu tanah yang diberikan sultan untuk dikelola secara individu dengan sistem pembagian bagi hasil dalam bentuk upeti. ${ }^{3}$ Selain itu juga dikenal penguasaan tanah yang bersifat sementara.

Pola penguasaan tanah di atas dalam perkembangannya semakin hari terpinggirkan akibat politik hukum pertanahan yang tidak tegas melakukan pengaturan dan perlindungan terhadap hak masyarakat adat setempat, dan secara internal dipengaruhi perkembangan masyarakat yang cenderung meninggalkan Adat Se Atorang (perilaku sesuai adat istiadat). Akibatnya terjadi perebutan tanah baik oleh pemerintah, pengusaha maupun antar masyarakat. Pemerintah dan pengusaha dianggap telah mengambil tanah masyarakat tanpa ada kompensasi yang seimbang. ${ }^{4}$ Masyarakat merasa diabaikan dan tidak mendapatkan manfaat atas lahan yang notabene telah dikuasai secara turun temurun dan telah menjadi sumber kehidupan mereka.

Memperhatikan uraian di atas, maka tulisan ini berusaha untuk menganalisis persoalan yang terkait dengan dinamika hukum yang mengatur pengakuan dan perlindungan hak atas tanah terhadap masyarakat hukum adat Ternate.

\section{Pembahasan Konsep Dinamika Hukum}

Adatrechbundels Beorgd Door de Commissse Vor Het Adatrecht en Uitgegeven Dor Het Koninklijk Institut Voor de Taal, Land-en Volkenkunde van nederlandschIndie. hlm. 7.

4 Faktanya pengakuan, penghormatan, perlindungan, pemberdayaan dan pengembangan terhadap hak-hak masyarakat adat belum diwujudnyatakan secara baik. Akibatnya timbul konflik kepentingan masyarakat adat dan pemerintah, bahkan antara masyarakat adat dengan masyarakat adat. Lily Bauw dan Bambang Sugiono, "Pengaturan Hak Masyarakat Hukum Adat di Papua Dalam Pemanfaatan Sumber Daya Alam", Jurnal Konstitusi, Vol. I No. 1, J uni 2009, J akarta: MKRI, hlm. 116117. 
Hukum mempunyai dinamika yang dapat diketahui melalui penelusuran pemikiran dan kebijakan yang terjadi pada masa lampau, guna membenahi masa kini dan memprediksikan yang akan terjadi ke depan. Menurut Hans Kelsen sebagaimana dikutip Achmad Sodiki ${ }^{5}$ dinamika atau perubahan di bidang hukum berwujud perubahan hukum sebagai suatu sistem tertutup dan ataupun sistem terbuka. Perubahan hukum sebagai suatu sistem tertutup -dinamika internal hukum - jika mengutip pendapat Kelsen yakni perubahan hukum yang berlangsung berdasarkan tingkatan hierarkhi hukum. Di samping itu terdapat perubahan yang berlangsung di dalam masyarakat seperti ketaatan masyarakat terhadap hukum. Perubahan terakhir ini berupa perubahan nilai-nilai, sikap, dan tingkah laku masyarakat terhadap hukum, atau dengan kata lain adanya dinamika eksternal hukum. ${ }^{6}$

Perubahan hukum yang mengatur permasalahan pertanahan sangat tergantung pada politik hukum pemerintah, sekaligus dipengaruhi oleh konstelasi politik yang terjadi pada saat itu. ${ }^{7}$ Dalam kehidupan bernegara, fenomena sosial dan hukum itulah kemudian mengkristal dalam bentuk peraturan perundangundangan.

Pandangan lain dikemukakan Niklas Luhmann melalui teori yang disebut "the theory of society as functionally differentiated social system" ${ }^{8}$ Dari pendapat Luhmann maka sistem hukum adalah suatu sistem yang normatif tertutup (normative closed system). Walaupun demikian, pada saat yang sama sistem hukum merupakan sistem yang kognitif terbuka (cognitive open system). Ketertutupan dan keter-

5 Achmad Sodiki. 1994. Penataan Kepemilikan Hak Atas Tanah di Daerah Perkebunan Kabupaten Malang. (Studi tentang Dinamika Hukum). Disertasi, Program Pasca Sarj ana Universitas Airlangga. Surabaya, hlm. 43.

6 Ibid. hlm. 44.

7 Lihat konfirgurasi politik dan hukum dalam Moh Mahfud, MD, 1999. Pergulatan Politik dan Hukum di Indonesia, Yogyakarta: Gamamedia, hlm. 4 Lihat dan bandingkan dengan Hasnati, "Pertautan Kekuasaan Politik dan Negara Hukum", J urnal Hukum Respublica, Vol. 3 No.1, Tahun 2003, Pekanbaru: Fakultas Hukum Universitas Lancang Kuning, hlm. 102-113.

8 Niklas Luhmann, 1988," "The Self Reproduction of law and its Limits" dalam Gunther Teubner, (ed), Dilemma of law in the Welfare State, New York, hlm. 112. bukaan bukan merupakan kontradiksi tetapi dua kondisi yang timbal balik.

Sebagai suatu sistem yang secara normatif tertutup maka kedudukan antara komponen-komponen sistem adalah simetris, sedangkan hubungan dengan lingkungan adalah asimetris. Operasional sistem adalah bergantung kepada lingkungan dan menyesuaikan diri dengan perubahan kondisi. Teori "Self referential legal system" yang membedakan antara normatif dan kognitif orientasi sekaligus membedakan, mengkombinasikan antara keterbukaan dan ketertutupan system. ${ }^{9}$

Selama ini, politik hukum penguasaan tanah yang diberlakukan pemerintah Indonesia bersifat normatif (hukum negara) dan sangat tertutup terhadap fakta sosial (pluralisme hukum) dalam masyarakat yang masih teguh mempertahankan dan melaksanakan penguasaan dan pengelolaan tanah berdasarkan hukum adat. Padahal sangat banyak konsep dan asasasas hukum adat yang dapat memberikan sumbangsih terhadap pembentukan hukum nasional.

\section{Konsep Pengakuan dan Perlindungan}

Pengakuan (erkenning) secara terminologi berarti proses, cara, perbuatan mengaku atau mengakui, sedangkan mengakui berarti menyatakan berhak. Pengakuan dalam konteks keberadaan suatu negara/pemerintahan yang secara nyata menjalankan kekuasaan efektif pada suatu wilayah yang disebut dengan pengakuan de facto, selain pengakuan secara hukum (de jure) yang diikuti dengan tindakantindakan hukum tertentu seperti pertukaran diplomatik dan pembuatan perjanjian-perjanjian kedua negara.

Kelsen, dalam bukunya "General Theory of Law and State", ${ }^{10}$ menguraikan pengakuan dalam kaitan dengan keberadaan suatu negara sebagai berikut:

Terdapat dua tindakan dalam suatu pengakuan yakni tindakan politik dan tindakan hukum. Tindakan politik mengakui

\section{Ibid. hlm. 48}

10 Hans Kelsen, 1973. General Theory of Law and State, (alih bahasa Somarno), J akarta: Rimdi Press, hlm. 222. 
suatu negara (baca keberadaan masyarakat hukum adat-penulis) berarti negara mengakui berkehendak untuk mengadakan hubungan-hubungan politik dan hubungan-hubungan lain dengan masyarakat yang diakuinya. Sedangkan tindakan hukum adalah prosedur yang dikemukakan di atas yang ditetapkan oleh hukum internasional (baca hukum nasionalpenulis) untuk menetapkan fakta negara (masyarakat adat-penulis) dalam suatu kasus konkrit.

Penetapan hukum negara (hukum positif) sebagai satu-satunya hukum yang mengatur kehidupan masyarakat kemudian dikritik oleh para pengikut mashab sejarah yang meyakini bahwa setiap masyarakat memiliki ciri khas masing-masing tergantung pada riwayat hidup dan struktur sosial yang hidup dan berkembang mengatur kepentingan mereka. Savigni melihat hukum sebagai fenomena historis, sehingga keberadaan setiap hukum adalah berbeda, bergantung pada tempat dan waktu berlakunya hukum. Hukum harus dipandang sebagai penjelmaan dari jiwa atau rohani suatu bangsa (Volksgeits) $^{11}$.

Konsep volksgeist Savigni, dipertegas oleh Eugene Ehrlich menyebutkan dengan fakta-fakta hukum (fact of law) dan hukum yang hidup dalam masyarakat (living law of people) yang berpandangan bahwa dalam setiap masyarakat terdapat aturan hukum-hukum yang hidup (living law). Semua hukum sebagai hukum sosial, dalam arti bahwa semua hubungan hukum ditandai faktor-faktor sosial-ekonomi.

Pengakuan bersyarat yang selama ini diterapkan oleh pemerintah (sepanjang masih ada dan tidak bertentangan dengan peraturan perundang-undangan) $)^{12}$ sangat merugikan masyarakat. Dengan demikian dapat dikatakan telah terjadi penundukan hukum adat terhadap

11 Lihat Farida Patittingi, "Peranan Hukum Adat Dalam Pembinaan Hukum Nasional Dalam Era Globalisasi", Majalah IImu Hukum Amanna Gappa, Vol. 11 No. 13, J anuari-Maret 2003, Makassar: Fakultas Hukum Universitas Hasanudin, hlm. 411.

12 Lihat penjelasan tentang hal ini pada Jufrina Rizal, "Perkembangan Hukum Adat Sebagai Living Law Dalam Masyarakat", J urnal IImu Hukum Amanna Gappa, Vol. 16 No. 1, Maret 2008, Makassar: Fakultas Hukum Universitas Hasanudin, hlm. 27 hukum negara yang oleh Griffiths disebut sebagai pluralisme hukum lemah, ${ }^{13}$ dimana berlakunya hukum adat, jika diakui oleh negara.

\section{Konsep Hak Masyarakat Hukum Adat}

Adat-istiadat mempunyai ikatan dan pengaruh yang kuat dalam masyarakat. Kekuatan mengikat tergantung pada masyarakat yang mendukung adat-istiadat tersebut, terutama berpangkal tolak pada perasaan kebersamaan, idealisme dan keadilan. Sulit untuk dibayangkan bahwa adat-istiadat walaupun dipelihara terus-menerus, dengan sendirinya akan mewujudkan kepastian hukum jika terdapat kaidah-kaidah mengikat yang mengatur tata kehidupan masa kini dan masa yang akan datang. ${ }^{14}$

Membedakan adat dan hukum adat dapat dilihat dari kaidah-kaidah yang hidup dalam masyarakat dan diberikan sanksi bagi pihak yang melanggar kaidah tersebut. Malinowski menyatakan bahwa perbedaan kebiasaan dengan hukum didasarkan pada dua kriteria, yakni sumber sanksi dan pelaksanaannya. Pada kebiasaan sumber sanksi dan pelaksanaannya ada pada warga masyarakat secara individu dan kelompok, sedangkan pada hukum sanksi dan pelaksanaannya ada pada suatu kekuatan terpusat atau badan-badan tertentu dalam masyarakat.

Penilaian pakar hukum di atas menurut penulis lebih cenderung melihat hukum adat dari aspek sanksi yang diterapkan oleh suatu otoritas/penguasa, ketika suatu individu melakukan pelanggaran atas norma yang disepakati. Walaupun demikian, tidak selamanya hukum

13 Lihat penjelasan konsep ini dalam Bernard Steny, "Pluralisme Hukum: Antara Perda Pengakuan Masyarakat Adat dan Otonomi Hukum Lokal", J urnal Pembaruan Desa dan Agraria, Vol. 3 No. 3, Tahun 2006, hlm. 84-85.

14 Penjelasan panjang lebar mengenai hal ini dapat dibaca pada Achmad Sodiki, Masalah konflik Peraturan Perundang-undangan dan Konflik di Lapangan Agraria dan Usulan Penanganannya (Mencari Format Penanganan Konflik Agraria dalam rangka Implementasi TAP MPR No IX/ MPR/ 2001), Makalah disampaikan sebagai Penanggap Utama dalam Seminar Nasional Strategi Pelaksanaan Pembaharuan Agraria, 26 September 2002, Jakarta, hlm. 3; Lihat juga Teddy Anggoro, "Kajian Hukum Masyarakat Hukum Adat dan HAM dalam Lingkup Negara Kesatuan Republik Indonesia", J urnal Hukum dan Pembangunan, Vol. 36 No. 4, Oktober-Desember 2006, Jakarta: Fakultas Hukum Universitas Indonesia, hlm. 489. 
adat tersebut identik dengan pemberian sanksi. Pada masyarakat tertentu, sanksi merupakan alternatif terakhir ketika seseorang tidak menaati norma yang hidup dalam masyarakat. Paling penting bagi masyarakat adalah hukum adat tersebut dapat memberikan rasa aman dan menciptakan ketertiban dalam hubungan sosial. Sanksi tidak selamanya diberikan oleh suatu otoritas atau institusi berkuasa, namun ada juga yang diberikan oleh masyarakat secara langsung melalui pembatasan pergaulan atau interaksi sosial yang dilakukan.

Dapat disimpulkan bahwa hukum adat ${ }^{15}$ dimaknai dalam penulisan ini adalah hukum adat yang mengandung unsur-unsur membentuknya, seperti terdapat adat-istiadat sebagai nilai-nilai yang telah melembaga dalam masyarakat melalui perbuatan-perbuatan masyarakat, mengandung norma yang disepakati bersama secara tidak tertulis, memiliki institusi atau organisasi yang menegakan, memiliki sanksi serta dipengaruhi oleh agama yang dianut pada masyarakat. Nilai-nilai dan norma-norma yang telah mendapatkan kesepakatan masa lalu, dalam kehidupan modern masih menjadi rujukan sebagai kearifan lokal (local wisdom). ${ }^{16}$

Selanjutnya menurut penulis secara substansial memberikan pemahaman bahwa hukum adat merupakan hukum yang selalu hidup dan berkembang dalam masyarakat, yang selalu mengikuti perkembangan jaman, memberikan jaminan ketertiban bagi masyarakat, serta mampu memberikan keadilan. Hukum adat bertujuan menciptakan kedamaian dan memajukan kesejahteraan bagi warga masyarakat. Sedangkan hak masyarakat hukum adat merupakan hak bersifat individu maupun hak yang bersifat komunal. Salah satu hak yang bersifat komunal

15 Istilah masyarakat adat diambil dari terjemahan kata indigenous peoples yang dibedakan dengan istilah masyarakat hukum adat yang merupakan terjemahan dari Belanda yakni rechtgemencshap. Lihat dalam Masyhud Asyhari, "Pemberdayaan Hak-Hak Rakyat atas Tanah", J urnal Hukum lus Quia lustum, Vol. 13 No. 7, April 2000. hlm, 108-109; dan Jawahir THontowi, "Komunitas Lokal dalam Perspektif HAM dan Hukum Nasional", J urnal Hukum, Vol. 57, Juli 2005, hlm. 245.

16 Jawahir Thontowi, op.cit, hlm. 239-240. Lihat juga Rachmad Syafa'at, "Kearifan Lokal dalam Masyarakat Adat di Indonesia", J urnal Publica, Vol. 4 No. 1, J anuari 2008, Malang: FISIP UMM, hlm. 8-15. yang terdapat dalam UUPA adalah hak ulayat (wilayah) untuk menunjukan kepada tanah yang merupakan wilayah lingkungan masyarakat hukum bersangkutan. Menurut Achmad Sodiki konsep penguasaan tanah berlaku pada masyarakat tradisional salah satunya adalah hak ulayat, yaitu suatu hak masyarakat hukum sebagai suatu kesatuan yang mempunyai wewenang ke luar dan ke dalam, serta didalamnya terdapat hak individu atas tanah yakni hak yang lahir karena pengusahaan yang terus menerus secara intensif atas sebidang tanah (kosong). ${ }^{17}$ Sedangkan Muchsin mendefenisikan hak ulayat sebagai hak yang dipunyai oleh masyarakat hukum adat tertentu atas wilayah tertentu yang merupakan lingkungan hidup para warganya untuk mengambil manfaat dari sumberdaya alam, termasuk tanah dalam wilayah tersebut bagi kelangsungan hidup dan kehidupannya. ${ }^{18}$ Pengakuan terhadap hak ulayat menunjukkan adanya kebolehan warga Negara, secara adat untuk memiliki atau menguasai tanah secara kolektif bagi terpenuhinya kepentingan bersama, namun juga pengakuan hak atas tanah secara pribadi diperkenankan. ${ }^{19}$

\section{Dinamika Hukum Pengakuan dan Perlindung- an Hak Atas Tanah Masyarakat Hukum Adat}

Sebelum masuknya penjajah (pra kolonial) di Maluku Utara, penguasaan tanah lebih banyak diatur oleh kelembagaan kerajaan/ sultan. Konsep kepemilikan eigendom tidak dikenal dalam mekanisme pengelolaan tanah pada zaman ini, yang lebih menonjol adalah penguasaan tanah yang dilakukan secara bersama-sama (komunal). Pada masa ini, tanah bukannya dimiliki oleh pejabat atau penguasa, dalam artian politik mempunyai hak yuridiksi atas tanah dalam wilayahnya yang dengan kekuasaan dan pengaruhnya dapat dipertahankan,

17 Achmad Sodiki, 1994, Penataan Kepemilikan Hak Atas Tanah di Daerah Perkebunan Kabupaten Malang. (Studi tentang Dinamika Hukum), Disertasi, Program Pasca Sarjana Universitas Airlangga, Surabaya, hlm. 21.

18 Muchsin, "Kedudukan Tanah Ulayat Dalam Sistem Hukum Tanah Nasional", Varia Peradilan Ikahi J akarta, XXI (245) April 2006, hlm. 35.

19 Ni'matul Huda, "Beberapa Kendala dalam Penyelesaian Status Hukum Tanah Bekas Swapraja di Daerah Istimewa Yogyakarta", J urnal Hukum, Vol. 13 No. 7 April 2000, Yogyakarta: Fakultas Hukum UII, hlm. 108. 
dan secara teoritik juga mempunyai hak untuk menguasai, menggunakan atau menjual hasilhasil buminya sesuai dengan adat yang berlaku.

Penguasaan tanah pada masyarakat hukum adat Ternate sebelum datangnya para penjajah dikuasai oleh soanang/momole (penguasa adat), kemudian setelah terbentuknya kerajaan di Maluku Utara, maka hak penguasaan tanah tersebut beralih kepada sultan sebagai kepala negara dan kepala pemerintahan sesuai hirarkhi hak yang berlaku dalam hukum adat. Penguasaan tanah paling tertinggi adalah hak kolano (hak Sultan) sekaligus sebagai sumber hak-hak yang lebih rendah. Hak kolano didistribusikan kepada masyarakat untuk dimanfaatkan demi kehidupan dan kemakmuran masyarakat adat, dengan pemberian upeti (ngase) dari hasil yang diperoleh sebagai bukti pengabdian kepada sultan.

Penguasaan politik yang dilakukan oleh kaum penjajah (Portugis, Spanyol, Belanda, Inggris, dan Jepang) dengan maksud agar lebih leluasa menghimpun dan menguasai berbagai sumber daya yang dimiliki masyarakat hukum adat Ternate. Akibatnya masyarakat diwajibkan untuk menyerahkan seluruh hasil bumi kepada Portugis dengan imbalan pembayaran yang sangat murah, diwajibkan untuk menyerahkan bahan bangunan dan tenaga kerja. Walaupun politik pertanahan pada saat itu memberikan hak penguasaan tanah masyarakat kepada masyarakat hukum adat, namun terdapat sebagian hak atas tanah masyarakat diambil secara paksa untuk kepentingan penjajah, kalaupun diberikan ganti rugi, dilakukan dengan harga yang sangat murah. Kebijakan pertanahan dan sumberdaya alam yang dilakukan penjajah untuk memperkokoh kekuasaan disegala bidang (SDA, Hukum, Politik, Pertahanan dan Perdagangan), dengan tujuan agar hasil yang di peroleh dapat memberikan kontribusi terhadap perekonomian bangsa mereka.

Masuknya bangsa Spanyol tidak merubah kondisi masyarakat hukum adat Ternate menjadi baik, bahkan dengan pola yang sama Spanyol menguasai berbagai sumberdaya alam yang dimiliki. Harga cengkih dibeli dengan standar harga lokal, tanah masyarakat dikuasai dengan hak barat melalui politik hukum pemerintah Spanyol. Wilayah Ternate dibagi dalam dua wilayah, sebelah utara dikuasai dengan hukum adat, dan wilayah selatan dikuasai dengan hukum barat (Spanyol). Penguasaan sumberdaya alam terus dilakukan dengan memanfaatkan potensi yang dimiliki masyarakat hukum adat Ternate, akibatnya kehidupan masyarakat tetap melarat/miskin sementara bangsa Spanyol semakin kaya. Sama halnya dengan bangsa Portugis, keberadaan Spanyol dengan tujuan untuk menghimpun dan mengambil sumberdaya alam rempah-rempah yang bernilai ekonomis, untuk diperdagangkan di pasar internasional, guna membiayai perekonomian negaranya.

Untuk memberikan perlawanan kepada bangsa Spanyol, Sultan Ternate melakukan keja sama dengan Belanda, dengan harapan dapat mengakhiri penjajahan di wilayah Ternate dan sekitarnya. Namun harapan tersebut tidak diperoleh, bahkan kehadiran bangsa Belanda merupakan babak baru penguasaan masyarakat beserta sumberdaya alam yang dimiliki. Kerjasama dengan bangsa Belanda dibebani dengan beberapa persyaratan seperti Belanda harus bebas untuk memberikan benteng, Ternate secara politik harus mengakui pembesar Belanda, biaya yang dikeluarkan untuk membiayai tentara Belanda ditanggung oleh masyarakat Ternate, serta harus memberikan monopoli hasil rempah-rempah. Bahkan Belanda harus diberikan hak untuk menentukan kepemimpinan lokal.

Pada saat itu pula, hukum adat diakui sepanjang tidak bertentangan dengan kepentingan Belanda. Saat VOC (verenigde oostindische compagnie) berkuasa tahun 1602-1799, politik hukum pertanahan tidak mengindahkan dan memperdulikan hak-hak tanah rakyat termasuk hak-hak masyarakat hukum adat, pengaturan, pemilikan, dan penguasaan tanah diatur dengan hukum Barat. Hukum adat sebagai hukum yang mempunyai corak dan sistem tersendiri tidak dipersoalkan VOC, bahkan membiarkan rakyat Indonesia hidup menurut adat dan kebiasaannya. 
Setelah VOC bangkrut, kemudian Inggris menguasai Hindia Belanda, Raffles memperkenalkan teorinya yang dikenal dengan teori domein yaitu penerapan sistem penarikan pajak bumi seperti yang dipergunakan Inggris di India. Dalam menghadapi kondisi yang berbeda dengan India, di Indonesia dilakukan penyelidikan kondisi agraria, kesimpulannya bahwa semua tanah adalah milik raja atau pemerintah. Kemudian dibuatlah sistem penarikan pajak bumi (Landrente) dimana setiap petani diwajibkan membayar pajak sebesar 2,5 dari hasil tanah garapannya.

Setelah kekuasaan kembali ditangan Belanda (1816-1829), terjadi perdebatan di kalangan pemerintah Belanda, berkaitan dengan asas dan corak kebijaksanaan agraria yang semuanya didasarkan pada pandangan bahwa negara adalah sebagai pemilik tanah atau negara yang mempunyai tanah (staatseigendom). Akibatnya terdapat perkembangan pemikiran dalam 2 kategori yakni, pertama aliran Asia yang didasarkan kepada hak kekuasaan dari Raja Asia dan kedua adalah aliran barat yang lahir dari paham barat, berhadapan dengan hak sewa dari petani yang sah.

Pengakuan dan perlindungan hak masyarakat hukum adat semakin terpuruk dengan diberlakukan politik hukum agraria melalui Regerings-Reglement (RR 1854) melalui S. 1855 No. 2 oleh Gubernur J endral A.J. Duymaer van Twest, dimana politik pemerintah tetap didasarkan pada azas, bahwa kekuasaan Belanda di daerah jajahan harus dipertahankan dengan jalan damai, dan dengan memperhatikan kemakmuran rakyat anak negeri, tanah jajahan harus memberikan keuntungan lahir kepada negeri Belanda. Agar tercapai tujuan tersebut rakyat asli selalu diperintah menurut adat istiadatnya, dengan tidak menyimpang dari peraturan perundangan-undangan yang adil dan langsung di bawah pimpinan kepala-kepalanya sendiri, tetapi selalu dijaga adanya perkosaan dan kelalaian. ${ }^{20}$

Pemberlakuan Regerings-Reglement (RR 1854) dengan pandangan bahwa pemerintah

20 R. Roestandi Adiwilaga, 1962, Hukum Agraria Indonesia, Bandung: NV. Masa Baru, hlm. 133. berhak atas tanah yang diusahakan oleh rakyat, terutama yang berkaitan dengan landrente, cultures dan menjual tanah kecil. Pembatasan Kewenangan Gubernur J endral juga dirumuskan dalam pasal 62 R.R, S. 1854 yang tidak memberikan kewenangan untuk melakukan transaksi jual beli tanah namun dapat disewakan.

Sebagaimana telah dirumuskan dalam S. 1854, Belanda tidak mempunyai pendirian yang jelas terhadap hak-hak atas tanah. Keraguan tersebut disebabkan karena (1) tidak ada sama sekali tertulis tentang hak tanah rakyat asli atau pun penduduk pribumi, (2) kurang mengerti dan memahami pengetahuan tentang hukum adat; (3) kesalahan-kesalahan dalam penyelidikan kearah itu, yang selalu diselaraskan dengan pengertian dan pengetahuan hukum barat.

Pasal 62 RR 1854 dalam perjalanannya dianggap jauh memuaskan bagi upaya untuk memberikan kesempatan bagi pemilik modal untuk membangun perkebunan besar, akibat dari politik monopoli dari negara dalam pengusahaan tanaman-tanaman yang mempunyai nilai ekspor bagi perusahaan swasta dengan hak eigendom (tanah partikel), sementara pada sisi lain akibat dari keberhasilan usahanya, perusahaan besar Belanda memerlukan bidang usaha baru untuk menginvestasikan modalnya di wilayah Hindia Belanda Kondisi ini sejalan dengan semangat liberalisme yang sedang berkembang dengan menuntut pergantian sistem monopoli negara dengan kerja paksa melalui konsep kapitalisme.

Dorongan dan tuntutan dari pengusaha besar di atas, dijawab oleh Pemerintah Belanda melalui politik pertanahan kolonial tahun 1870 dengan melakukan penambahan 5 ayat baru, kemudian ditambah 3 ayat dari pasal 62 RR 1854 sehingga menjadi 8 ayat. Pasal 62 RR dengan delapan ayat ini kemudian dijadikan pasal 51 dari Indische Staatsregeling (IS), yang kemudian peraturan tersebut dikenal dengan nama agrarische Wet (S. 1870. No.55). terkait hak masyarakat adat terhadap tanah diatur bahwa bagi Gubernur Jenderal tidak boleh mengambil tanah kepunyaan hak rakyat asal pembukaan hutan yang digunakan untuk ke- 
perluan sendiri, milik desa, dan tempat pengembalaan umum, hak-hak atas tanah orang pribumi yang diperoleh secara turun-temurun dapat diberikan dengan hak eigendom. Walaupun dalam peraturan ini memberikan pengakuan terhadap hak masyarakat hukum adat, namun pada saat bersama diberikan pembatasan hanya pada tanah-tanah yang dikuasai langsung oleh masyarakat. Bagi tanah yang tidak dikuasai secara langsung, maka tanah tersebut menjadi tanah milik (eigendom) negara yang diatur melalui peraturan pelaksana dari Agrarische Wet, dan dikenal dengan pernyataan kepemilikan atau domein verklaring, ${ }^{21}$ melalui peraturan pasal 1 agrarische besluit (S 1879. No 118) sebagai peraturan pelaksanaan dari Agrarische Wet.

Dampak dari pernyataan domein verklaring ini, menyebabkan tanah-tanah yang dipunyai oleh rakyat melalui hak milik adat adalah merupakan tanah milik negara, sedangkan dalam konteks administrasi pertanahan tanah-tanah hak milik adat dikenal sebagai onvrij lands domein (tanah negara tidak bebas), dengan kata lain negara tidak bebas untuk memberikan tanah yang bersangkutan kepada lain karena dibebani hak rakyat. ${ }^{22}$

Setelah Indonesia merdeka, upaya untuk mengakhiri penguasaan sumberdaya tanah yang berlebihan oleh penjajah terus dilakukan melalui pembentukan hukum agraria nasional yang berpihak kepada masyarakat. Disadari, tanah merupakan pemberian Tuhan kepada seluruh umat manusia, serta memahami kondisi bangsa indonesia yang bercorak agraris dimana masyarakat tidak dapat terlepas dari tanah, maka filosofi tanah bagi petani merupakan dasar pembentukan hukum tanah nasional.

Filosofi tanah untuk petani ini kemudian dirumuskan dalam Undang-Undang No. 5 tahun 1960 tentang Peraturan Dasar Pokok-Pokok Agraria, sekaligus menghapus dualisme hukum yang berlaku dalam pengaturan masalah

\footnotetext{
21 Lihat mengenai domain verklaring ini pada Sukirno, "Perlindungan Hukum Masyarakat Hukum Adat", J urnal Masalah-Masalah Hukum, Vol. 37 No. 2, J uni 2008, Semarang: Fakultas Hukum Universitas Diponegoro, hlm. 135-140.

22 B.F. Sihombing, op.cit, hlm. 89.
}

pertanahan, domeinverklaring, feodalisme dan pembentukan hukum agraria nasional didasarkan pada hukum adat karena dipandang sesuai dengan kepribadian bangsa Indonesia serta merupakan hukum rakyat Indonesia yang asli. Sebagai jawaban atas Ketidakadilan dari peraturan-peraturan agraria zaman kolonial ${ }^{23}$, maka dalam UUPA diamanatkan untuk dilakukan penataan struktur kepemilikan dan penguasaan tanah, serta hubungan hukum antara orang dengan tanah dan hubungan antara orang dengan perbuatan hukum yang berhubungan dengan tanah. ${ }^{24}$

Tentunya filosofi dasar diatas dengan maksud agar para petani dapat meningkatkan kemakmuran dan kesejahteraan melalui tanah sebagai basic need (kebutuhan dasar) bagi rakyat Indonesia. Terwujudnya nilai kepastian hukum, keadilan, serta kegunaan/ kemanfaatan, barulah ada artinya jika hal tersebut menjadikan petani makmur dan sejahtera. Namun dalam perkembangannya, nilai dasar tersebut telah bergeser akibat pengaruh kapitalisme yang mempengaruhi sistem perekonomian Indonesia. Bukti nyata pengaruh tersebut dapat dilihat melalui kebijakan politik hukum Pemerintah Orde Baru yang mengundangkan peraturan sektoral yang lebih mementingkan kepentingan investor (UU No. 11 tahun 1967 tentang pertambangan, UU No. 5 tahun 1967 tentang Kehutanan, UU No. 1 Tahun 1974 tentang pengairan, dan lain-lain). Penguasaan sumber daya alam telah diorientasikan sebagai milik negara dan swasta. Berdasarkan realitas tersebut, menurut Achmad Sodiki bahwa sekalipun secara yuridis formal UUPA masih berlaku tetapi secara filosofis sudah kehilangan nilainilai kerakyatan yang harus diwujudkan. ${ }^{25}$

Dengan demikian, menurut penulis bahwa tanah yang diberikan kepada seseorang, ke-

23 Achmad Sodiki, Masalah Konflik Peraturan PerundangUndangan dan konflik di Lapangan Agraria dan Usulan Penanganannya, Mencari Format Penanganan Konflik Agraria dalam rangka Implementasi TAP MPR No: IX/ MPR/2001, Makalah disampaikan sebagai Penanggap Utama dalam Seminar Nasional Strategi Pelaksanaan Pembaharuan Agraria, 26 September 2002, hlm. 1.

24 Pasal 2 ayat (2) UU No. 5 tahun 1960 tentang Peraturan Dasar Pokok-Pokok Agraria

25 Achmad Sodiki, op. cit, hlm. 2. 
lompok, maupun swasta bukan semata-mata untuk mengejar produktivitas tanpa batas, tetapi lebih diutamakan bagi kebutuhan seperlunya. Hasil pengelolaan tanah berupa pangan, bukan menjadi monopoli sepihak, akan tetapi pangan harus diperuntukan bagi kebutuhan dasar semua orang, terutama masyarakat miskin.

Penguasaan tanah di Maluku Utara (Ternate) di zaman sebelum terbentuknya kerajaan, yang mewakili persekutuan hukum (rechtsgemeenschap) disebut Momole (Ternate), Soanang (Bacan) yakni penguasa atas tanah. Kekuasaan momole atau kepala-kepala Soanang atas kaula mereka sebenarnya tidak terlalu besar. Mereka tidak lebih dari kepala suku dan pemangku adat dalam komunitasnya dan wilayah adat. Setelah terbentuknya kerajaan, Sultan adalah tuan tanah. Hak pertuanan (beshikingrechts) atas tanah terletak pada Sultan yang dalam hal ini bertindak sebagai penanggungjawab dari persekutuan hukum dalam kerajaannya.

Rakyat suatu wilayah tahu sebelum adanya raja, momole/soanang telah lebih dahulu ada dan menjadi penguasa atas tanah. Bila seorang warga akan membuka kebun sagu atau kelapa, maka ia harus memperoleh ijin momole/ soanang sebagai kepala adat/penguasa, dan apabila si pemilik kebun meninggalkan tanah perkebunannya, maka kebun itu jatuh kepada momole/ soanang.

Setelah terbentuknya kerajaan, pada Masyarakat adat Ternate telah diakui terbentuknya suatu lembaga adat tertinggi yang berdiri di atas semua lembaga-lembaga lainnya, dikenal dengan "Kolo Lamo" yakni lembaga hukum adat tertinggi. Dalam pergaulan masyarakat Moloku Kie Raha (Ternate) terdapat tindakantindakan manusia untuk mengamankan dan memajukan kepentingan-kepentingannya, termasuk pada bidang pengelolaan sumber daya alam (tanah).

Masyarakat adat Ternate mengakui bahwa hak atas tanah berada pada kolo lamo, sebagai lembaga kekuasaan hukum tertinggi. Berdasarkan asas "jou sengofa ngare" (falsafah hukum adat Moluku Kie Raha), maka kolano menyerahkan semua hak atas tanah kepada
Soa, sehingga praktis dalam tiap-tiap lingkungan hukum adat, yaitu ternate dan sekitarnya, (Tidore, Bacan dan Jailolo), semua tanah habis terbagi kepada soa (rechtgemeen schap).

Setelah terbentuknya Pemerintah Swapraja pada tahun 1912, Pemerintah Swapraja mengadakan rapat umum yang disebut rapat kie (empat kerajaan: kerajaan Ternate, Tidore, Bacan dan Jailolo) yang dihadiri oleh semua sangaji (gelar kepala komunitas tradisional/ kepala distrik dan merupakan golongan tertinggi), Gimalaha (kepala distrik), famanyira (kepala desa/ kepala soa), para kepala kampung dan seluruh pimpinan soa (suatu daerah/ lingkungan wilayah) dengan keputusan pada saat itu, berupa tanah cocatu tetap dipertahankan dan diakui sebagai milik rakyat, dan pemegang cocatu diharuskan membawa akte cocatu yang bertuliskan huruf arab tersebut untuk dilegalisir oleh residen; dan Aha kolano dikuasai oleh Pemerintah Swapraja.

Penguasaan tanah yang berlaku pada masyarakat hukum adat Ternate dapat dibagi hak atas tanah yang bersifat tetap seperti aha kolano/raki kolano, aha soa, aha cocatu, dan hak atas tanah yang bersifat sementara seperti hak safa/hak teto, hak tolagami, hak rubabanga, hak jurame.

Melalui politik hukum pemerintah, hakhak masyarakat hukum adat semakin hari mengalami degradasi akibat dari desakan kebijakan pemerintah yang hanya melihat tanah dari aspek ekonomi semata. Bahkan, pada kalangan tertentu adat dan hukum adat justru ditakuti sebagai suatu bahaya atau ancaman peradaban demokrasi dan nilai kemanusiaan. Adat juga diperkirakan bisa mengancam sistim politik modern yang rasional. Kondisi ini disebabkan karena adat dan hukum adat tidak ditempatkan dalam pengertian sebagai suatu sistem mengatur dan menyelenggarakan kehidupan dalam komunitas.

Penguasaan tanah dan penyelesaiaan sengketa berdasarkan hukum adat, sampai saat ini masih dikenal pada masyarakat hukum adat 
yang tersebar di seluruh Indonesia. ${ }^{26}$ Dengan kata lain, bahwa eksistensi masyarakat hukum adat beserta hak tradisionalnya sangat tergantung syarat yang ditentukan oleh negara yakni sepanjang masih hidup, sesuai dengan perkembangan jaman, sesuai dengan prinsip NKRI dan diatur oleh undang-undang (Pasal 18B UUD 1945, dan pasal 5 UU No 5 tahun 1960 tentang Peraturan Dasar Pokok-Pokok Agraria).

Persyaratan pemberlakuan di atas, menunjukkan terjadi penundukan hukum adat terhadap hukum negara, dimana berlakunya hukum adat jika diakui oleh hukum negara. Penundukan Pemberlakuan hukum adat terhadap hukum negara menunjukkan bahkan hukum negara lebih superior dibandingkan dengan hukum adat yang menurut keberadaan hukum adat bergantung dengan belas kasihan undangundang. Dengan demikian, berlakunya hukum adat harus tidak bertentangan dengan peraturan perundangan negara. Kondisi ini yang dianut oleh UUPA, dimana hukum adat dianggap terdapat kekurangan yang harus dibersihkan dengan menggunakan kriteria hukum nasional. ${ }^{27}$

Dapat dipahami bila hukum adat ditempatkan dibawah UU, ketika UUPA dirumuskan pada saat belum diberlakukannya amandemen UUD 1945. Kondisi ini tentunya sangat berbeda saat ini, karena bila diteliti dalam konstitusi, hukum adat beserta hak tradisional dipandang sebagai hak konstitusional sekaligus sebagai hak asasi manusia yang diatur dengan undangundang. Dengan demikian, maka sepantasnya hukum adat ditempatkan pada kedudukan yang sejajar dengan undang-undang ${ }^{28}$. Kesejajaran ini memberikan berbagai alternatif bagi masyarakat hukum adat, maupun pihak luar untuk melakukan pilihan hukum ketika terjadi suatu

26 Lihat dalam Kaimuddin Salle, "Hukum Adat Bagaikan Embun", Jurnal de Jure, Vol. 2 No. 2, Mei 2006, Malang: LP3M Fakultas Syariah UIN, hIm. 37 dan Aan E. Widiarto, "Prospek Alternatif Penyelesaian Sengketa (APS) dalam Perspektif Hukum Adat untuk Menyelesaikan Konflik Pertanahan di Indonesia", Arena Hukum, Vol. 22 No. 7, Maret 2004, Surabaya: Fakultas Hukum Universitas Airlangga, hlm. 35.

27 Achmad Sodiki, "Politik Hukum Agraria, Univikasi ataukah Pluralisme Hukum", Arena Hukum, Vol. 8 No. 3, Maret 1999, Surabaya: Fakultas Hukum Universitas Airlangga, hlm. 103.

28 lbid. hlm. 103. hubungan hukum yang mengatur kepentingankepentingan mereka.

Pengakuan hak atas tanah berdasarkan hukum adat merupakan konsekuensi dari keberadaan masyarakat yang otonom, untuk mengatur hubungan hukumnya. Dengan kata lain, pada masyarakat hukum adat terdapat kepastian kelompok-kelompok sosial (social field) dalam mencipta-kan mekanisme-mekanisme pengaturan pengelolaan dan pemanfaatan tanah tersendiri (self-regulation) dengan disertai kekuatan pemaksa pentaatannya melalui norma hukum dan institusi yang diakui. Namun pada saat yang ber-samaan terdapat campur tangan dari pihak luar (negara), maka keberadaan masyarakat beserta norma yang telah disepakati tersebut menjadi semi otonom karena dipengaruhi oleh faktor eksternal. Pengaruh faktor eksternal menyebabkan terjadinya keberagaman hukum yang saling mempengaruhi secara dinamis dalam perilaku sosial masyarakat yang beragam. Hal ini sejalan dengan teori Semi-Autonomous Social Field yang dikemukakan oleh Moore. Reali-tas ini, oleh Achmad Sodiki dinamakan ter-jadi pengaruh pada dinamika internal dan eksternal hukum dalam masyarakat. Dalam kaitan tanah adat, B.F. Sihombing membagi dalam dua jenis, yakni hukum tanah adat yang terjadi pada masa lampau dan hukum tanah adat yang terjadi pada masa kini. ${ }^{29}$

Melalui kriteria dan fakta keberadaan pengelolaan sumber daya alam tanah pada masyarakat hukum adat Ternate, maka menurut penulis ciri-ciri hak masyarakat hukum adat atas tanah adalah pertama, terdapat sumberdaya alam (tanah, hutan, tambang, air) yang berada

29 Hukum Tanah Adat masa Iampau ialah hak memiliki dan menquasai sebidang tanah pada zaman penjajahan Belanda dan Jepang. Serta pada zaman Indonesia merdeka tahun 1945, tanpa bukti kepemilikan secara otentik maupun tertulis, jadi hanya pengakuan. Adapun ciri-ciri hukum tanah masa lampau adalah tanah-tanah yang dimiliki dan dikuasai oleh seseorang dan atau sekelompok masyarakat adat yang memiliki dan menguasai serta menggarap, mengerjakan secara tetap maupun berpindah-pindah dengan daerah, suku, dan budaya hukumnya, kemudian secara turun temurun masih berada di lokasi daerah tersebut, dan atau mempunyai tanda-tanda fisik berupa sawah, ladang, hutan, dan simbol-simbol berupa makam, patung, rumah-rumah adat, dan dan bahasa daerah sesuai dengan daerah yang ada di Negara Republik Indonesia. B.F. Sihombing, op cit, hlm. 67 . 
dalam wilayah masyarakat hukum adat; kedua, dimiliki dan atau dikuasai oleh sekelompok orang atau individu; ketiga, dikerjakan secara tetap maupun berpindah-pindah dalam wilayah hukumnya; keempat, secara turun temurun masih berada di lokasi daerah tersebut, atau telah berpindah tangan atau dialihkan; kelima, mempunyai tanda-tanda fisik berupa sawah, ladang, hutan, dan simbol-simbol berupa makam, patung, rumah-rumah adat, dan dan bahasa daerah; keenam, terdata institusi adat yang mengatur penggunaan, dan pemanfaatannya; ketujuh, memiliki norma yang disepakati bersama oleh masyarakat hukum adat; dan kedelapan, mempunyai bukti pemilikan baik secara tertulis, maupun melalui pengakuan oleh warga masyarakat.

Sesuai dengan ciri-ciri yang dikemukakan, baik berdasarkan pada hukum tanah adat masa lampau maupun masa kini, pada masyarakat hukum adat Ternate masih berlaku hukum adat yang mengatur tentang tanah, seperti yang dikenal hak bersifat tetap aha kolano (tanah sultan), aha soa (tanah kampung) dan aha cocatu (tanah individu), maupun hak bersifat sementara seperti hak tolagami (hak buka lahan), hak safa (hak penandah tanah), hak rububanga (bongkar hutan) dan hak jurame (kebun yang telah ditinggalkan), yang sampai saat ini masih dipraktikkan dalam pengelolaan sumberdaya tanah. Namun demikian, karena berlakunya sangat tergantung pada hukum negara, maka hak-hak tersebut semakin hari terreduksi dan menyesuaikan diri dengan perkembangan masyarakat, akibat dari politik hukum agraria nasional. Bahkan hak-hak tersebut tidak mendapat perlindungan layak baik pada saat berhadapan dengan kasus konkrit, maupun dalam produk hukum negara, walaupun telah memenuhi kriteria yang terdapat dalam Peraturan Menteri Agraria No. 9 tahun 1999 tentang pedoman penyelesaian hak ulayat masyarakat hukum adat.

\section{Penutup \\ Simpulan}

Berdasarkan uraian yang dikemukakan di atas, maka dalam tulisan ini dapat disimpulkan bahwa pertama, hak atas tanah masyarakat hukum adat saat ini masih banyak terdapat di seluruh wilayah Indonesia, walaupun dari satu masyarakat hukum adat yang satu dengan yang lainnya terdapat perbedaan berdasarkan pada adat dan kebiasaan yang diyakni; kedua, perkembangan penguasaan hak atas tanah di Indonesia mengalami pasang surut, kondisi ini sangat terkait dengan sistem dan konstalasi politik yang berlaku pada saat itu; ketiga, terhadap hak masyarakat hukum adat di Maluku Utara, khususnya di Ternate, sampai saat ini masih eksis, hal ini ditandai dengan adanya masyarakat hukum adat yang selalui menjaga dan melestarikannya, terdapat regulasi atau norma yang mengatur serta adanya wilayah yang menjadi tempat mencari nafkah dan penghidupan sehari-hari. Walaupun demikian, kebijakan pemerintah sampai saat ini belum memberikan perlindungan terhadap keberadaan dan keberlangsungannya.

\section{Saran}

Berdasarkan simpulan di atas, terdapat beberapa rekomendasi dari penulis berupa pertama, untuk memberikan perlindungan terhadap masyarakat hukum adat beserta kearifan lokalnya, maka Pemerintah dan DPR perlu segera merumuskan Undang-Undang sebagaimana diamanatkan dalam pasal 18B ayat (2) UndangUndang Dasar Negara Republik Indonesia tahun 1945; Kedua, sambil menunggu ditetapkannya Undang-Undang yang mengatur kesatuan masyarakat hukum adat beserta hak tradisionalnya, pada tataran lokal dengan kewenangan otonomi daerah Pemerintah Daerah dan DPRD perlu merumuskan dan membentuk Peraturan Daerah yang dapat menjamin perlindungan terhadap hak masyarakat hukum adat; Ketiga, pemerintah perlu melakukan inventarisasi hukum adat dan hak tradisional yang masih ada saat ini sebagai bahan pembentukan hukum kedepan.

\section{Daftar Pustaka}

Adiwilaga, R Roestandi. 1962. Hukum Agraria Indonesia. Bandung: NV. Masa Baru; 
Anggoro, Teddy. "Kajian Hukum Ma-syarakat Hukum Adat dan HAM dalam Lingkup Negara Kesatuan Republik Indonesia". J urnal Hukum dan Pembangunan. Vol. 36 No. 4. Oktober-Desember 2006. J akarta: Fakultas Hukum Universitas Indonesia;

Asyhari, Masyhud. "Pemberdayaan Hak-Hak Rakyat atas Tanah". Jurnal Hukum lus Quia lustum. Vol. 13 No. 7. April 2000;

Bauw, Lily dan Bambang Sugiono. "Pengaturan Hak Masyarakat Hukum Adat di Papua Dalam Pemanfaatan Sumber Daya Alam", J urnal Konstitusi. Vol. I No. 1. J uni 2009. J akarta: MKRI;

Haba, John. "Realitas Masyara-kat Adat di Indonesia; Sebuah Realitas". J urnal Masyarakat dan Budaya. Vol. 12 No. 2. Tahun 2010. Jakarta: LIPI;

Hasnati, "Pertautan Kekuasaan Politik dan Negara Hukum", J urnal Hukum Respublica Vol. 3 No. 1. Tahun 2003. Pekanbaru: FH Universitas Lancang Kuning;

Huda, Ni'matul . "Beberapa Kendala dalam Penyelesaian Status Hukum Tanah Bekas Swapraja di Daerah Istimewa Yogyakarta", J urnal Hukum Vol. 13 No. 7. April 2000. Yogyakarta: Fakultas Hukum UII;

Kelsen, Hans. 1973. General Theory of Law and State. (alih bahasa Somarno). J akarta: Rimdi Press;

MD, Moh Mahfud. 1999. Pergulatan Politik dan Hukum di Indonesia. Yogyakarta: Gamamedia;

Muchsin, "Kedudukan Tanah Ulayat Dalam Sistem Hukum Tanah Nasional", Varia Peradilan. Vol. 21 No. 245. April 2006, J akarta: IKAHI;

Patittingi, Farida. "Peranan Hukum Adat Dalam Pembinaan Hukum Nasional Dalam Era Globalisasi". Majalah IImu Hukum Amanna Gappa. Vol. 11 No. 13 J anuari-Maret 2003. FH Universitas Hasanudin;

Rizal, Jufrina. "Perkembangan Hukum Adat Sebagai Living Law Dalam Masyarakat", J urnal IImu Hukum Amanna Gappa. Vol. 16 No. 1. Maret 2008. FH Universitas Hasanudin;

Salle, Kaimuddin. "Hukum Adat Bagaikan Embun", Jurnal de Jure. Vol. 2 No. 2. Mei 2006. LP3M Fakultas Syariah UIN Malang;

Sodiki, Achmad. 1994. Penataan Kepemilikan Hak Atas Tanah di Daerah Perkebunan Kabupaten Malang. (Studi tentang Dina- mika Hukum). Disertasi. Surabaya: Program Pascasarjana Universitas Airlangga;

"Politik Hukum Agraria, Univikasi ataukah Pluralisme Hukum". Arena Hukum. Vol. 8 No. 3. Maret 1999. Surabaya: Fakultas Hukum Universitas Airlangga;

1994. Penataan Kepemilikan Hak Atas Tanah di Daerah Perkebunan Kabupaten Malang. (Studi tentang Dinamika Hukum). Disertasi. Surabaya: Program Pasca Sarjana Universitas Airlangga;

- Masalah konflik Peraturan Perundangundangan dan Konflik di Lapangan Agraria dan Usulan Penanganannya (Mencari Format Penanganan Konflik Agraria dalam rangka Implementasi TAP MPR No IX/MPR/2001), Makalah disampaikan sebagai Penanggap Utama dalam Seminar Nasional Strategi Pelaksanaan Pembaharuan Agraria pada tanggal 26 September 2002. J akarta;

“Kebijakan Sumber Daya Alam dan Implikasi Juridisnya Pasca TAP MPR N IX/MPR/ 2001 dan Kepres No 34 tahun 2003". makalah pada Seminar Nasional dengan tema: Eksistensi dan Kewenangan BPN Pasca Keppres No 34 tahun 2003. Malang;

Steny, Bernard. "Pluralisme Hukum: Antara Perda Pengakuan Masyarakat Adat dan Otonomi Hukum Lokal", Jurnal Pembaruan Desa dan Agraria. Vol. 3 No. 3. Tahun 2006;

Sukirno. "Perlindungan Hukum Masyarakat Hukum Adat". Jurnal Masalah-Masalah Hukum Vol. 37 No. 2. J uni 2008. Semarang: Fakultas Hukum Universitas Diponegoro;

Syafa'at, Rachmad. "Kearifan Lokal dalam Masyarakat Adat di Indonesia". Jurnal Publica. Vol. 4 No. 1. J anuari 2008. Malang: FISIP UMM;

Teubner, Gunther. (ed). 1988. Dilemma of law in the Welfare State. New York;

Thontowi, Jawahir. "Komunitas Lokal dalam Perspektif HAM dan Hukum Nasional". Jurnal Hukum Fakultas Hukum Unisia. Vol. 57. J uli 2005;

Widiarto, Aan E. "Prospek Alternatif Penyelesaian Sengketa (APS) dalam Perspektif Hukum Adat untuk Menyelesaikan Konflik Pertanahan di Indonesia". Arena Hukum Vol. 22 No.7. Maret 2004. Surabaya: Fakultas Hukum Universitas Airlangga. 